\title{
Evaluation of Changchun Jingyuetan National Scenic Spot Ecosystem Services, China
}

\author{
Qiu Lei \\ Yingkou Environmental Assessment Co., Ltd \\ Yingkou, Liaoning, China \\ Cui Peng \\ School of Environmental Science \\ Northeast Normal University \\ Changchun, Jilin, China
}

\author{
Lv Li-sha \\ School of Environmental Science \\ Northeast Normal University \\ Changchun, Jilin, China \\ Sun Shi-jun ${ }^{*}$ \\ School of Environmental Science \\ Northeast Normal University \\ Changchun, Jilin, China \\ (*Corresponding Author, sunsj763@nenu.edu.cn)
}

\begin{abstract}
Changchun Jingyuetan National Scenic Spot is a sophisticated ecosystem, to explicit the functions and values of ecological products, ecological process, and to offer information for decision makers, a range of appropriate ecological assessment methods: opportunity cost approach, cost analysis, human capital approach, the asset value method, travel cost method, willingness to pay method, were taken to evaluated the worth of scenic spot. The research find out that ecosystem service valuation of Changchun Jingyuetan National Scenic Spot is RMB 1420.7089 million, social value of providing ecosystems production, recreation places and employment accounting for $1.84 \%$ of the total value. The public services function value, selection value, heritage value and existing value account for $98.2 \%$ of the total value. Ecosystem value, which has been liable to be neglected by traditional development concept, is much more significant than its social economic value. The evaluation of Changchun Jingyuetan National Scenic Spot is conducive to its future development.
\end{abstract}

Keywords: ecosystem services; evaluation; Changchun Jingyuetan National Scenic Spot; market valuation method; shadow project approach

\section{INTRODUCTION}

The "ecosystem services" can be traced firstly in "Man's Impact on the Global Environment" by SCEP (Study of Critical Environmental Problems) in 1970. The document lists the pest control, insect pollination etc. eight aspects of natural ecosystems to human “environmental services" function [1]. Since 1997 Costanza came up with the monetization calculations for the economic value of global ecosystem services, valuation of ecosystem services has become a hot spot in ecological research gradually, and many evaluation methods have been put forward [2-3]. These methods were successfully used to assess the environmental services for various types of ecosystems [4].

In this study, we took Changchun Jingyuetan National Scenic Spot as example, which is located in the southeast of Changchun City, Jilin province, China, to define the types of ecosystem service. The assessment was conducted based on the related references and some research results, coupled with the existing data and our experiment data. Then we conduct detailed analysis to assess the ecosystem services according to market valuation method, shadow project approach and willingness to pay method. Eventually, we worked out the total ecosystem services of the system.

\section{RESEARCH METHODS}

In this paper, the value of ecosystem was estimated by specific mathematical method: opportunity cost approach, cost analysis, the asset value method, travel cost method, willingness to pay method, and the effectiveness and accuracy of these methods were confirmed by extensive applications [5-7].

\section{ASSESSMENT OF ECOSYSTEM SERVICES VALUE}

The Ecosystem services was divided into two different parts, i.e. use value and non-use value; use value was further split into direct use value and indirect use value, non-use value was divided to selective value, heritage value and existing value by Pearce [8].

\section{A. Direct Use Value}

1) Providing ecosystem products: The ecosystem of Changchun Jingyuetan National Scenic Spot was mainly composed of forest ecosystems, aquatic ecosystems and farmland ecosystem. These ecosystem services refer to providing of food, wood and other materials, which was essential to human living.

The ecosystem services was assessed based on market valuation method, and the result indicated that the ecosystem services for forest ecosystems was 61.36 million yuan, for farmland ecosystem was 32.88 million yuan, for the irrigation water was 4.52 million yuan per year. The total value of ecosystem products was about 102.19 million yuan per year.

2) The social value of providing recreational areas and employment: The value of providing a recreational area is calculated based on travel expense and time costs of the tourists, this part of value were about 197.10 million yuan. The wages and benefits of 42 employees in the spot are 
another part of social value; these parts were about 1.26 million yuan/a.

\section{B. Indirect Use Value}

In addition to direct monetization of "the function of providing ecosystem products”, Changchun Jingyuetan National Scenic Spot also has indirect value - "public service functions of improving the human living environment".

1) Public service functions of forest ecosystems: The public service functions of forest ecosystem mainly include the purifying atmosphere, water conservation, soil conservation, carbon sequestration, oxygen release and accumulation of nutrients.

a) Purifying the atmosphere: Forest ecological system can provide the following functions: absorption of atmospheric pollutants, such as sulfur dioxide, nitrogen oxides, dust, heavy metals etc.; filtration, barrier and decomposition, noise reduction and provision of negative ions and terpenes material (such as phytoncid) [9]. According to calculation, the value of providing negative ion is 7680 million/a, absorbing contaminants and dust is 29,892 million yuan/a; reducing noise is 14.72 million yuan/a.

b) Water conservation: Water system function is reflected in three aspects: the increase of water resources, water purification and regulation of runoff. The value of regulating water quantity is 230.00 million yuan/a and unifying water quality is 8.77 million yuan/a.

c) Soil conservation: The living things and the litter layers in forest reduce the impact of water drop on the surface and erode surface runoff; simultaneously, tree root soil prevent soil erosion, reducing soil fertility loss and improving soil structure [10]. Calculation shows that soil reinforcement's value of is 24.40 million yuan/a. The fertilizer conservation value which calculated based on fertilizer prices, is 18551.45 million yuan/a.

d) Carbon sequestration and oxygen release: It is a kind of function that forest ecosystems fix carbon and release oxygen through forest vegetation, soil, animals and micro-organisms. It can be calculated that the value of Jingyuetan forest ecosystem in fixing carbon is 2590.92 million yuan.

e) The accumulation of nutrients: Biochemical reaction enable forest plants absorb nutrients from the atmosphere, soil and sediment. This function is of great significance in non-point source pollution and eutrophication control downstream. It can be calculated that the value of nutritive material which accumulated by forest ecosystems is 5.15 million yuan/a.

2) Public service function of farmland ecosystem:

a) Value of air purification: The function of farmland ecosystems purifying the atmosphere is mainly reflected in the absorption of pollutants and dust [11]. Monetary estimates of this function is the integration of farmland area and exhaust gas treatment price, which is 26.20 million yuan/a.

b) Value of water conservation: Soil moisture content in study area is $77.25 \times 10^{3} \mathrm{~kg} \cdot \mathrm{hm}^{-2} \cdot \mathrm{a}^{-1}$ according to our research. Then, the service value of the water source of farmland ecosystem in scenic areas is 1.66 million yuan/a by using the shadow engineering method for quantitative evaluation.

c) The accumulation of nutrients: The quantity of $\mathrm{N}$, $\mathrm{P}$, and $\mathrm{K}$ in farmland crops can be obtained by experimental analysis. According to the shadow engineering method for monetizing, it can be estimated that the value of the agricultural ecosystem in maintaining the nutrient cycling is 2404.9665 million yuan.

3) Public services function of water ecosystem: Water ecosystem regulating services mainly contains regulating floods, ground water recharge, water purification and air conditioning.

a) Flood storage value: Lakes have very significant roles in regulating runoff, reducing the flood peak and the storage. Jingyuetan reservoir can not only retain the watershed upstream, lag upstream flood process, reduce pressure of the downstream flood and reduce economic losses caused by floods. This study used shadow engineering method to account the value of flood regulation of Jingyuetan, the result is 162.87 million/a.

b) Groundwater recharge value: Jingyuetan reservoir water and ground water are connected by groundwater recharge. Jingyuetan reservoir becomes groundwater aquifers, thus is maintained as a part of the shallow layer groundwater system, which supply to the surrounding water, eventually flowing into the deep groundwater system turning to long-term headwaters. Value of the function is estimated about 0.97 billion/a.

c) Water purification Value: Jingyuetan reservoir water ecological system has a certain degree of self purification capacity. The purification of water functional performance is reflected in absorbing and using the waste through dilution, diffusion, adsorption, filtration, oxidation decomposition [12]. Water purification value is calculated as 0.9213 million yuan/a.

d) Adjust atmospheric value: The $\mathrm{CO}_{2}$ in atmosphere which is fixed by plant photosynthesis is the important source of carbon cycle in the ecosystem, the water ecosystem of lake has a huge buffer effect on the increase of $\mathrm{CO}_{2}$ concentration in the atmosphere. $\mathrm{O}_{2}$ is released by aquatic higher plants, which is essential for the maintenance of life activities of the earth. With the reference of industrial oxygen industry shadow price, the total value of ecosystem oxygen release can be calculated as 0.46 billion yuan in 2010 .

\section{Non-use Value}

1) Selection Value: The estimation of Jingyuetan scenic area's heritage value and existence value is based on questionnaire survey results. 150 questionnaires were collected each survey, including 120 questionnaires from tourists and 30 questionnaires from expert, the efficiency of the questionnaire was 92 percent. According to the amount of average annual tourists, it can be reckoned that the selection value is 121.53 million yuan/a.

2) Heritage value: As an AAAA level scenic spot, Changchun Jingyuetan National Scenic Spot has significant heritage value. Therefore, it is not enough to reflect the heritage value of the system if we only to calculate the willingness to pay (WTP) value of tourists, therefore, the WTP value given by tourists will be revised by experts (weight of expert opinion is 0.6 , weight of tourist opinion 0.4). According to the amount of average annual tourists $(1095,000)$, it can be calculated that the 
heritage value of is 0.12 million yuan/a.

3) Existing value: Same as the value of heritage, the WTP value given by tourists will be revised by experts' existing value. In design of questionnaire, we set that how much you are willing to pay for ensuring that the scenery and the environment quality here would not decline. According to the amount of annual received tourists, it can be calculated that the existing value of Changchun Jingyuetan National Scenic Spot is 171.66 million yuan/a.

\section{Summary of Main Ecosystem Services Value}

It can be calculated that the main ecosystems services value of the scenic area is 1420.7089 million yuan/a, the specific value of each ecosystem services listed in Table 1 .

\section{TABLE I. SUMMARY OF ECOSYSTEM SERVICE VALUE TABLE TYPE STYLES}

\begin{tabular}{|c|c|c|c|}
\hline \multicolumn{2}{|c|}{ Ecosystem Service Function } & \multirow{2}{*}{$\begin{array}{c}\begin{array}{c}\text { Ecosystem } \\
\text { Service } \\
\text { Function } \\
\text { (million) }\end{array} \\
6.136\end{array}$} & \multirow{3}{*}{$\begin{array}{c}\begin{array}{c}\text { Total } \\
\text { (million) }\end{array} \\
25.972\end{array}$} \\
\hline \multirow{2}{*}{$\begin{array}{c}\text { Direct } \\
\text { use value }\end{array}$} & $\begin{array}{c}\text { Providing ecosystem } \\
\text { products }\end{array}$ & & \\
\hline & $\begin{array}{c}\text { The social value of } \\
\text { providing recreational } \\
\text { areas and employment }\end{array}$ & 19.836 & \\
\hline \multirow{3}{*}{$\begin{array}{c}\text { Indirect } \\
\text { use value }\end{array}$} & $\begin{array}{l}\text { Public service functions } \\
\text { of forest ecosystems }\end{array}$ & 1095.2135 & \multirow{3}{*}{1353.2731} \\
\hline & $\begin{array}{l}\text { Public service function } \\
\text { of farmland ecosystem }\end{array}$ & 240.6655 & \\
\hline & $\begin{array}{l}\text { Public services function } \\
\text { of water ecosystem }\end{array}$ & 17.3941 & \\
\hline \multirow{3}{*}{$\begin{array}{c}\text { Non-use } \\
\text { value }\end{array}$} & Selective value & 12.1534 & \multirow{3}{*}{41.4638} \\
\hline & Heritage value & 12.1446 & \\
\hline & Existing value & 17.1658 & \\
\hline $\begin{array}{c}\text { Total } \\
\text { (million) }\end{array}$ & \multicolumn{3}{|c|}{1420.7089} \\
\hline
\end{tabular}

\section{CONCLUSION}

The main ecosystems services value of Changchun Jingyuetan National Scenic Spot is 1420.7089 million yuan/a, among which 0.2597 billion yuan/a is the social value of providing ecosystems production, recreation places and employment accounting for $1.84 \%$ of the total value. The public services function value, selection value, heritage value and existing value account for $98.2 \%$ of the total value. Ecosystem value is much more significant than its social economic value. Furthermore, the public services function of forest ecosystem is far more important than that of water and farmland ecosystem. This shows that the public services function is very significant, especially in fixing carbon and releasing oxygen, preventing soil erosion and maintaining soil fertility.

As the scenic area is located in the suburbs of the city, it nourished the development of the real estate, commerce and other industries in the surrounding area. This study has not estimated this part due to the lack of relevant data and the difficulty of calculating the related benefit. This part of ecosystem value will be estimated in future research.

\section{REFERENCES}

[1] SCEP (Study of Critical Environmental Problems), “Man’s impact on the global environment: assessment and recommendations for action”, MIT Press, Cambridge MA, 1970, pp. 103-105.

[2] J. Holder and P.R. Ehrlich, "Human population and global environment”. American Scientist, vol. 62, 1974, pp. 282-297.

[3] A. R. Costanza and C. Folke, "Valuing ecosystem services with efficiency”, Fairness, and Sustainability as Goals in Nature's Services, 1997, pp. 49-68.

[4] A. M. Alexander, J. A. List, “A method for valuing global ecosystem services”, Ecological Economics, vol. 27, 1998, pp. 161-170.

[5] A. Grêt-Regameya, P. Bebib, I. D. Bishopc, W. A. Schmida, "Linking GIS-based models to value ecosystem services in an alpine region”, Journal of Environmental Management, Vol. 89, Nov. 2008, pp. 197-208.

[6] C. Gowan, K. Stephenson and L. Shabman, "The role of ecosystem valuation in environmental decision making: Hydropower relicensing and dam removal on the Elwha River", Ecological Economics, vol. 56, 2006, pp. 508-523.

[7] N. J. Beaumont, M. C. Austen, J. P. Atkins, D. Burdon, S. Degraer, T. P. Dentinho, D. P. Holm, T. Horton, E. V. Ierland, A. H. Marboe, D. J. Starkey, M. Townsend and T. Zarzycki, "Identification, definition and quantification of goods and services provided by marine biodiversity: Implications for the ecosystem approach”, Marine Pollution Bulletin, vol. 54, 2007, pp. 253-265.

[8] D. Pearce, D. Moran, “The economic value of biodiversity”, 1994 Earthscan, London, pp. 66-69.

[9] C. D. Ivesa, D. Kendalb, "The role of social values in the management of ecological systems”, Journal of Environmental Management, vol. 144, Nov. 2014, pp. 67-72.

[10] G. X. Rousseaua, O. Deheuvelsb, I. R. Ariasd, E. Somarribae, "Indicating soil quality in cacao-based agroforestry systems and old-growth forests: the potential of soil macro fauna assemblage”, Ecological Indicators, vol. 23, Dec. 2012, pp. 535-543.

[11] D. F. Karnosky, K. E. Percy, A. H. Chappelka, S. V. Krupa, “Air pollution and global change impacts on forest ecosystems: monitoring and research needs”, Developments in Environmental Science, vol. 3, 2003, pp. 447-459.

[12] K. Taguchi, K. Nakata, "Evaluation of biological water purification functions of inland lakes using an aquatic ecosystem model", Ecological Modelling, vol. 220, Sep. 2009, pp. 2255-2271. 